\title{
Exploring gender perceptions of resource ownership and their implications for food security among rural livestock owners in Tanzania, Ethiopia, and Nicaragua
}

\author{
Alessandra Galiè ${ }^{\prime *}$, Annet Mulema², Maria A Mora Benard ${ }^{3}$, Sheila N Onzere ${ }^{1}$ and Kathleen E Colverson ${ }^{4}$
}

\begin{abstract}
Background: Productive resources are essential to the livelihoods and food security of the world's rural poor. Gender-equal ownership of resources is considered key to increasing agricultural productivity, equity, and food security. However, there has not been much research about local understandings of ownership particularly in the Global South. In addition, research is also lacking about how concepts of ownership affect food security at the household level.

Results: This paper discusses the variability of local understanding of ownership by showing seven domains resource ownership was associated with by a small cohort of respondents. It shows the flexibility of systems governing resource entitlements among the studied communities and their impact on food security. It shows that, irrespective of these understandings and systems, resource arrangements favored men.

Conclusions: The authors argue that an understanding of local meanings of ownership might reveal important and unnoticed aspects of resource allocation, as well as provide guidance for initiatives that seek to provide locally relevant approaches to improving gender equity.
\end{abstract}

Keywords: Ownership, Agricultural resources, Livestock, Food security, Gender, Tanzania, Ethiopia, Nicaragua

\section{Background}

Productive resources such as water, land, livestock, and crops are essential to the livelihoods of most of the world's rural families, particularly in the Global South [1]. And yet, poor rural women in the Global South often do not have the same level of ownership rights as their male counterparts. Such ownership rights are important-they are believed to increase women's household decision-making and empowerment, which in turn increase household efficiency in agricultural productivity as well as individual equity [2]. In addition, evidence suggests that even slight differences in intrahousehold allocation of scarce resources can dramatically impact child and female nutrition and health [3].

\footnotetext{
* Correspondence: a.galie@cgiar.org

'International Livestock Research Institute, P.O. Box 30709, Nairobi, Kenya Full list of author information is available at the end of the article
}

Laws and customs that negatively affect women's access to and control over resources hamper their economic advancement, particularly in Sub-Saharan Africa [4] and Latin America [5]. Unless an explicit gender equity lens is adopted in laws, general economic improvement will not strengthen women's property rights and might actually erode them-poor women will be largely unable to take advantage of the new agricultural technologies and farming techniques that such economic improvement might bring [6]. A number of authors have therefore argued that securing women's rights to resources is a way to enhance welfare, growth, equity, and empowerment $[7,8]$. Other authors, however, have criticized the assumption that promoting gender equity and women's resource ownership increases the efficiency of development interventions and promotes growth. For instance, research has found that ownership of agricultural assets by women does not necessarily entail 
their access to and control over resources, income, and/or food [9]. O'Laughlin [10] critically examines the emphasis on intra-household resource allocation as the basis of gender inequity-she argues that problems of poverty and gender inequity are not only about intra-household resource allocation but are also caused by wider dynamics, policies, and historical legacies that may be obscured by a focus on micro-level responsibilities.

A number of authors have focused on how the complexities of ownership arrangements stem from such structural, cultural, and historical contexts, and they argue that these contexts need to be taken into account when formulating strategies to enhance equity in resource ownership [11]. Men and women have been shown to have different types, quantities, and qualities of assets and to also have different strategies of accumulating resources and using them to deal with shocks. Jackson [12] and Razavi [13] have focused on the complexities of arrangements that regulate access to and control over resources at the village and household levels, and they argue against formalizing ownership systems because the ambiguity of rules may have strategic advantages for women.

Ample literature has also focused on the meaning of the term "ownership" itself. Ribot and Peluso [14] argue that property is often associated with socially acknowledged and supported claims or rights based on law, customs, and conventions. They emphasize the need to distinguish between "property" (or ownership) and "access," arguing that the former entails the "right to benefit from things" and the latter "the ability to derive benefits from things." Access therefore has more to do with "bundles of powers" (while property with "bundles of rights") and entails complex social relations that might change over time and space. "Control," in addition, differs from access, as it implies some form of decision-making power over objects or resources [1]. Bell [15] argues that "there can hardly be a word more freighted with meaning than 'property'." Johnson et al. [16] highlight how local definitions of asset ownership affect asset distribution in the household and the impact of interventions on women's asset ownership. They conclude that normative perceptions of gender roles strongly affect ownership distribution.

According to the "psychological ownership construct," formulated by Marks and Davis, ownership is "that state in which individuals feel as though the target of ownership (material or immaterial) or a piece of it is theirs" [17]. Marks and Davis claim that the key elements that cause a sense of ownership are 1) controlling, 2) intimately knowing, 3) investing oneself, and 4) a shared understanding in a given environment. Marks and Davis utilize psychological ownership studies to investigate the sense of ownership of water infrastructure in development projects in Sub-Saharan Africa. According to their study, a sense of ownership of water infrastructure is developed after there is 1) participation in planning and construction of the infrastructure (e.g., contributions of cash, land, and/or materials for the construction), 2) participation in key decisions about the project, and 3) contributions to the construction of the system.

Despite the various angles from which resource ownership has been studied, and despite acknowledgement that the term itself is ambiguous, limited research has been devoted to understanding what the term "ownership" might mean within local contexts in the Global South, especially from a gender perspective. Yet, "resource ownership" has become a common indicator in both quantitative and qualitative tools (surveys in particular), used by agriculture development projects to characterize intervention locations and assess impacts on household welfare and gender equity. This is the case for the CGIAR Research Program (CRP) on Livestock and Fish (L\&F) , whose work frames the issues reported in this study. Also, while several studies have been conducted to assess the relationship between women's asset ownership and food security, research is lacking on how concepts of ownership affect food security at the household level. In other words, "How do understandings of resource ownership affect who is involved in the production, provision, and preparation of food at the household level?"

This study aims to explore women's and men's understandings of ownership and their implications for food security in three countries where the CRP L\&F works within livestock value chains: 1) the smallholder dairy value chain in Tanzania, 2) the small ruminant value chain in Ethiopia, and 3) the dual-purpose cattle value chain in Nicaragua (see the "Methodology" section for details).

One disclaimer applies: the paper does not aim to provide either a comprehensive overview of the local meanings of ownership nor a comparison of these meanings across the research communities and countries. Rather, the paper aims to show the variability in the understandings of "ownership" that exists locally in the three countries-1) among a small number of respondents from the same communities and 2) within individuals who rephrased their understanding of the term over the course of the group discussions-vis-à-vis the utilization of the term as a universally shared concept both in agricultural research for development and development interventions.

The objectives of this study are

1) To generate an understanding of how women and men in different contexts might understand, perceive, or define the term "resource ownership," with a focus on livestock. 
2) To establish the relationship between the meanings attached to resource ownership and food security for the respondents in the three countries.

This paper is organized as follows: It first provides an overview of the methodology and methods utilized for the study. It then presents findings by introducing 1) resources considered important to food security and 2) what systems were in place to assign ownership, particularly of livestock. This initial overview of household ownership arrangements, as perceived by the respondents, was then used to explore 3) the main categories respondents associated ownership of livestock with, 4) gender norms affecting the distribution of resource ownership, and finally 5) the implications the above have for food security. The study ends with a discussion of the findings and how they can improve our understanding of food security and gender equity.

\section{Methods \\ Methodology}

This study was designed as small-N qualitative research [18]. A small-N approach [19] was preferred to a large-N statistical analysis because it was considered more appropriate for an in-depth understanding of the perceptions of "ownership" by the respondents and also for appreciating the causal links that respondents identified between "ownership" and "gender equity" and "ownership" and "food security" [20]. George and Bennett [21] argue that small- $\mathrm{N}$ qualitative research is particularly appropriate in exploratory studies conducted on issues about which little information exists. The outputs of small-N research can provide substantial descriptions and understandings of specific issues, identify correlations to related issues, provide new frames for thinking about known concepts, and generate questions that can be examined in large- $\mathrm{N}$ studies.

\section{The respondents and their villages}

Tanzania is located in East Africa. Income poverty-a combination of basic needs and food poverty-affected $34 \%$ of the population in 2007, with the highest percentages in rural areas. The population comprises more than 120 ethnic groups. The livelihoods and nutrition of over $80 \%$ of the country's population depend on crop and livestock production. Tanzanian women are estimated to provide $60 \%$ of food production [22].

Interviews were conducted with 57 female and 51 male respondents between the ages of 16 and 75 . These respondents were selected from Mvomero, Kongwa, and Lushoto districts. All three districts are predominantly rural with agriculture comprising the main livelihood activity and livestock keeping being a secondary activity. The following villages were selected: from Mvomero
District, Wami Luhindo, Wami Dakawa, Wami Sokoine, and Manyinga; from Kongwa District, Masinyeti, and Ihanda; and from Lushoto District, Lwandai and Viti (see Table 1 for household characteristics).

The villages selected were involved in two CRP L\&F projects for smallholder dairy value chains: MoreMilkiT and the Crops and Root project (CGP) ${ }^{\mathrm{b}}$. MoreMilkiT selected its villages based on the following criteria: seasonality of feed and milk production, low production of feed and milk, lack of fodder availability in the dry season, limited milk processing activities, and very low proportions of improved dairy cattle. The CGP selected crop-growing, goat-owning, and non-goat-owning farmers in the regions of Morogoro and Dodoma in Tanzania. Respondents for this study were selected by local extension officers based on their participation in the projects and their availability for interviews.

Ethiopia is located in the horn of Africa. It is one of the poorest nations in Africa and the most populous landlocked country in the world [23]. Ethiopia is a highly diverse country with over 80 different ethnic groups, with the two largest being the Oromo (34\%) and the Amhara (27\%) [24]. Agriculture is one of the major economic activities in the country which has a diverse range of climate and agro-ecological zones stretching from the dry Sahel to the humid equatorial zones which makes it ideal for livestock production.

The study was conducted in two Woredas (districts): Yabello and Atsbi (Table 1). Both districts are comprised of pastoral and agro-pastoral communities. Within the Borana community in Yabello, respondents for this study were drawn from Elwoye Kebele (the smallest administrative unit in an urban or rural center with its own jurisdiction). In Atsbi, they were selected from Golgol Neale and Habes Kebeles. A total of 18 livestock keepers were interviewed, including eight women and ten men. These were selected based on their livestock ownership and their availability and willingness to participate in the interview. The ages of men ranged from 20 to 55 and those of women from 25 to 50 .

The Kebeles selected are located within two of the action sites for the L\&F small ruminant value chain development project in Ethiopia. The criteria for selecting the sites were based on the potential of maximizing the contribution of the project to the livelihoods of smallholder, rural poor households ${ }^{\mathrm{c}}$.

Nicaragua is located in the Central American isthmus; it is the second poorest country on the American continent. A history of wars, revolutions, serious environmental problems, and high vulnerability to natural disasters has added to the current situation, in which $42.7 \%$ of the population lives in poverty and $7.6 \%$ in extreme poverty.

This research was conducted in the communities of Camoapa and Matiguás (located in the central northern and southern regions of the country) where livestock 
Table 1 Household characteristics in the study areas

\begin{tabular}{|c|c|c|c|c|c|c|c|c|}
\hline \multicolumn{9}{|c|}{ Household characteristics } \\
\hline \multirow{2}{*}{\multicolumn{2}{|c|}{$\begin{array}{l}\text { Country } \\
\text { District }\end{array}$}} & \multicolumn{3}{|l|}{ Tanzania } & \multicolumn{2}{|l|}{ Ethiopia } & \multicolumn{2}{|l|}{ Nicaragua } \\
\hline & & Kongwa & Mvomero & Lushoto & Yabello & Atsbi & Boaco & Matagalpa \\
\hline \multirow{6}{*}{$\begin{array}{l}\text { Population } \\
\text { characteristics }\end{array}$} & Males & 154,843 & 149,221 & 30,236 & 487,000 & 53,659 & 19,057 & 23,381 \\
\hline & Females & 157,266 & 160,752 & 262,205 & 475,400 & 58,682 & 20,035 & 23,036 \\
\hline & Total population & 309,109 & 312,109 & 492,441 & 962,400 & 112,341 & 39,092 & 46,417 \\
\hline & Total Ag HH & 50,735 & 58,314 & 94,075 & 174,474 & 26,425 & 7,058 & 8,828 \\
\hline & Average HH size & 5 & 4 & 4.7 & 7 & 5 & 5.5 & 5.2 \\
\hline & $\begin{array}{l}\% \text { female-headed } \\
\mathrm{HH}\end{array}$ & 29 & 19 & 26 & 28 & $15-30$ & 44 & 23 \\
\hline \multirow[t]{3}{*}{$\begin{array}{l}\text { Average HH } \\
\text { income (USD) }\end{array}$} & $\begin{array}{l}\text { Average } \mathrm{HH} \\
\text { income }\end{array}$ & 320 & 1,095 & 1,018 & 400 & 487 & N/A & N/A \\
\hline & Male-headed HH & 386 & 1,253 & 1,097 & 428 & 615 & N/A & $\mathrm{N} / \mathrm{A}$ \\
\hline & $\begin{array}{l}\text { Female-headed } \\
\mathrm{HH}\end{array}$ & 153 & 463 & 580 & 272 & 358 & N/A & N/A \\
\hline \multicolumn{2}{|l|}{ Agro-ecology } & $\begin{array}{l}\text { Semi-arid climate } \\
\text { with great } \\
\text { variability in } \\
\text { rainfall }\end{array}$ & $\begin{array}{l}\text { Semi-arid climate/ } \\
\text { comprised of three } \\
\text { agro-ecological zones }\end{array}$ & $\begin{array}{l}\text { Montane climate } \\
\text { with a bimodal } \\
\text { rainfall pattern } \\
(800-2,000 \mathrm{~mm} \\
\text { per annum) }\end{array}$ & $\begin{array}{l}\text { Drought-prone semi-arid } \\
\text { pastoral rangeland. Highly } \\
\text { variable spatial and temporal } \\
\text { features. Bimodal rainfall } \\
\text { ranging between } 300 \text { and } \\
900 \mathrm{~mm} \text { per annum }\end{array}$ & $\begin{array}{l}\text { Mild temperatures. Variable } \\
\text { topography—-mountains } \\
\text { alternating with wide plains. } \\
\text { Highly eroded slopes. Intense } \\
\text { rainfall of short duration } \\
\text { (annual average } 668 \mathrm{~mm} \text { ) }\end{array}$ & $\begin{array}{l}\text { Irregular mountainous } \\
\text { topography. Diverse } \\
\text { climate including } \\
\text { grasslands and } \\
\text { tropical forest }\end{array}$ & $\begin{array}{l}\text { Extensive } \\
\text { forests with } \\
\text { high annual } \\
\text { rainfall }(1,200- \\
1,900 \mathrm{~mm} \\
\text { per annum) }\end{array}$ \\
\hline \multicolumn{2}{|c|}{ Ag production system } & $\begin{array}{l}\text { Rain-fed } \\
\text { subsistence } \\
\text { farming, mixed } \\
\text { crop /livestock, } \\
\text { agro-pastoralism }\end{array}$ & $\begin{array}{l}\text { Rain-fed subsistence } \\
\text { farming, mixed } \\
\text { crop/livestock, } \\
\text { agro-pastoralism }\end{array}$ & $\begin{array}{l}\text { Mixed crop/livestock, } \\
\text { rain-fed agriculture } \\
\text { and irrigation } \\
\text { agriculture, } \\
\text { agro-pastoralism }\end{array}$ & $\begin{array}{l}\text { Mostly livestock production, } \\
\text { with some crop farming }\end{array}$ & $\begin{array}{l}\text { Rain-fed agriculture } \\
\text { with minimal irrigation. } \\
\text { Predominantly crop } \\
\text { production with } \\
\text { modest livestock } \\
\text { holdings }\end{array}$ & $\begin{array}{l}\text { Mixed crop/livestock. } \\
\text { Cattle production } \\
\text { predominantly based } \\
\text { on permanent } \\
\text { grazing of naturalized } \\
\text { grasslands. Rainfall } \\
\text { and irrigation } \\
\text { agriculture }\end{array}$ & $\begin{array}{l}\text { Mixed crop/ } \\
\text { livestock. } \\
\text { Cattle } \\
\text { production } \\
\text { predominantly } \\
\text { based on } \\
\text { permanent } \\
\text { grazing of } \\
\text { naturalized } \\
\text { grasslands. } \\
\text { Rainfall and } \\
\text { irrigation } \\
\text { agriculture }\end{array}$ \\
\hline \multicolumn{2}{|c|}{$\begin{array}{l}\text { Villages/communities } \\
\text { in the study }\end{array}$} & $\begin{array}{l}\text { 1. Masinyeti } \\
\text { 2. Ihanda }\end{array}$ & $\begin{array}{l}\text { 1. Wami Luhindo } \\
\text { 2. Wami Dakawa } \\
\text { 3. Wami Sokoine } \\
\text { 4. Mayinga }\end{array}$ & $\begin{array}{l}\text { 1. Lwandai } \\
\text { 2. Viti Lushoto }\end{array}$ & Elwoye & $\begin{array}{l}\text { 1. Golgol Neale } \\
\text { 2. Habes } \\
\text { 3. Gebrekidan }\end{array}$ & Camoapa & Matiguás \\
\hline
\end{tabular}


production has historically been the primary economic activity.

These communities are CRP L\&F sites, and the respondents were contacted through their links to local organizations identified during the program partners' scope. The respondents were six men and six women cattle farmers between the ages of 23 and 56 . For all of the respondents' households, the main livelihood activities depended on cattle raising for milk and meat production.

\section{Data collection and data analysis}

This research was conducted between December 2013 and March 2014, with 138 respondents (57 women and 51 men in Tanzania, eight women and ten men in Ethiopia, and six women and six men in Nicaragua) by three gender researchers involved with the CPR L\&F program. The research ethics of the study were addressed as follows: In all three research sites, respondents were briefed about the purpose of the study and the process involved and were assured of their anonymity and confidentiality. Verbal consent was then obtained from respondents to conduct the interviews with the agreement that the researchers would be able to use findings and statements in a research article. Tanzania is part to the international conventions that require ethical consideration in research. The research in Tanzania was done in collaboration with Sokoine University of Agriculture (SUA) which has an approved conduct for research ethics similar to COSTECH's-the national body charged with the responsibility of ensuring ethical research conduct. Ethiopia has no ethical body for research approval and ethical clearance is not required by the government. However, measures were utilized to minimize any harm to respondents including assuring confidentially and anonymity of participants. Oral approval was also obtained from the leaders of the national agricultural research institutions that collaborate with ILRI. Nicaragua has no ethical bodies for research approval and ethical clearance is not required by the government. However, institutional endorsement for the study was obtained by the local organizations that contacted the participants: the Municipal Development Association (ADM) in Camoapa and the Office for Local Economic Development (ODEL) in Matiguás.

In Tanzania, the study was conducted during two field visits. In Nicaragua, it was conducted during four field visits. In Ethiopia, it was conducted through three field visits. Semi-structured, participatory interviews were done with sex-disaggregated groups in each community (with the exception of Wami Dakawa in Tanzania, where men and women preferred not to separate). A translator was involved in the interviews in Tanzania and Ethiopia. The following questions were used to guide the discussions: "In your household, who owns what resources that are needed to successfully raise livestock?"; "How is this ownership assigned to household individuals and why?"; and "How does this ownership or lack of it affect food security in the household?"

In Tanzania, the Kiswahili word used for "ownership" was "Kumiliki" and "owner" was "Mmiliki" for both women and men. These words are formal but in common use in Tanzania and indicate "having rights over something." In Ethiopia, the Amharic word for "ownership" which was used to open the interviews was "Yema nibiret." It was translated into Tigranya as "Bealwana" (and "Bealwana Gal Aynaseti" for a female owner and "Bealwana Wedi Tebaty" for a male owner) and into Oromiffa as "Abbaa Kabegna" (with "Kabegna Dunfa Diraa" for a male owner and "Kabegna Dunfa Dubarti" for a woman). In Nicaragua, the words used to discuss ownership in Spanish were "dueño or dueña" which translates to English as "to be a (respectively male and female) owner." Dueño or dueña is defined as "someone who has dominion or control over something or someone, or that is the owner of something." The terms refer to owning something in a more broad sense than "propietario/propietaria"d and are more commonly used.

The interviews were digitally recorded and transcribed and verified with the respondents during follow-up visits. The information from the interviews was coded with the software package QSR NVivo 10 (International PTY 1999-2013) separately for each country and based on an agreed-upon set of codes derived from the interview questions $\mathrm{e}^{\mathrm{e}}$. The information was then analyzed to identify and compare commonalities and differences in meanings among respondents. Consensus analysis [25,26] was performed manually on the extracted statements about the meanings of ownership that were then grouped into seven main categories: "benefiting from livestock," "how livestock was sourced," "decision-making," "taking care of animals," "knowledge of resources," "having full authority over the livestock," and "carrying the responsibility."

\section{Results}

\section{Resources needed to raise livestock for food security}

This section provides an overview of what resources the respondents mentioned they needed to successfully raise their livestock in order to ensure food security.

In Tanzania, the resources mentioned by both female and male respondents as essential to successfully raising livestock and producing milk for food security are as follows (in descending order of importance): feeds, water, markets, vaccines, good breeds, information on how to preserve feeds and treat animals, and credit. Both the sale of milk and live animals provide revenues that can be used to purchase vegetables and, once a month, meat. Daily availability of milk for household consumption is said to enhance nutrition and the health of all household members, children in particular. The manure from livestock is considered to improve and increase the vegetable 
produce that is used either for food or for sale by women and men. Animals are sold for money in difficult moments and are therefore an important source of collateral against hunger.

Similar to Tanzania, male and female respondents in the three Kebeles from Ethiopia mentioned feed, water, markets, veterinary services, and credit as important resources for raising livestock and producing milk and butter. Credit and feed are important for fattening, while veterinary services are needed to keep animals healthy. In explaining the importance of markets, a male respondent from Gologo described markets as enabling livestock to function as a "living bank." For this respondent, the direct provision of milk, meat, eggs, manure, and draft power was augmented by the sale of animal products and of the livestock themselves that provided revenues to purchase additional food. This idea was also reflected by a female respondent from Elwoye, who stated, "For cattle, when you get hungry, you sell and buy grain. You can sell and buy anything you need." Land (both grazing and farmland), labor, and barns were also identified as major resources required by respondents from Elwoye. These respondents considered land the most important resource, since it is essential for grazing, production of fodder and crops, meat, residues that can be fed to animals to produce milk, and as a means of generating income. While grazing land and water were defined as "communal resources," veterinary services and markets were said to be "public resources." The remaining resources were considered to be privately owned.

In Camoapa and Matiguás, both male and female respondents identified land, water, improved pastures, credit, infrastructure (including roads and livestock facilities), technical assistance, and technology (in particular cattle breeds, artificial insemination services, and farm mechanical equipment) as the main resources needed to raise cattle and produce milk. Land, credit, and livestock facilities are said to be privately owned. Water is under private or public ownership depending on whether the water source is located on private or public land or if it is publicly supplied by the government. Land is the primary resource needed to raise livestock and grow crops. Milk and animal sales are sources of household income used to buy grains, vegetables, and sometimes meat. Most milk is sold to cooperatives and constitutes a significant contribution to household income; a small percentage is destined for household consumption, especially for children or used by women to make artisanal cheese called Cuajada, which is consumed in the household and sold locally.

Most female respondents from Nicaragua stated that they were mainly involved in four main activities that contributed to food security: raising livestock (cattle and pigs) and chickens, making/selling artisanal cheese, and planting crops. Male respondents said their main activities were livestock raising (cattle), marketing of milk/ live animals, and planting crops.

\section{Systems of ownership}

This section reports our findings on who owns what resources, when, and how, with a focus on livestock.

In Tanzania, the male and female respondents stated men were generally the owners of larger types of livestock (e.g., cattle, goats, and sheep) and larger areas of land; widows owned large and small types of livestock and differing amounts of milk; and married women owned smaller livestock (e.g., chickens) and less milk. Young unmarried women and men generally owned resources together with their parents. Smaller livestock-and chickens in particular-were also generally said by the men to belong to the whole family. In Manyinga, land was privately owned by men via written contracts while ownership of livestock was often simply "known" in the family and sometimes via an oral agreement. In contrast, land in Wami Dakawa and Wami Sokoine was public but was informally assigned to the heads of households (whether male or female, but generally male) by the village council. Ownership of livestock was also informal. Systems of ownership and their perceptions varied greatly by gender, village, and ethnic groups.

Livestock could be received through inheritance or divorce. In Wami Dakawa, boys and girls are given a cow at birth. However, when marrying, boys can claim the cow and its offspring while girls can only claim the cow in case they marry a poorer man. In all villages, in the case of a father's death, young men only inherit livestock, but only if they are of marriageable age and if they have "behaved responsibly." Opinions about ownership arrangements seemed to diverge between some respondent women and men. In the village of Lwandai, the women stated that women can own sheep, goats, and chickens while men own land and cattle. The respondent men, however, stated that men own all the livestock and added that chickens are owned by the whole family. In Viti, the respondent women stated that they owned the land and cattle with the men while the men interviewed stated that ownership of land and livestock is mostly for the men.

In Wami Luhindo, non-Maasai men and women agreed that they own land and livestock together; male Maasai respondents stated that men and women own all resources together while Maasai women argued women only own chickens and milk and the rest is owned by the men. Widows can own all resources, but only with the supervision of a male family member.

In Ethiopia initially, respondents reported that married people own resources jointly. At the time of marriage, male and female children are gifted a share of family resources (including livestock). This share is referred to 
as Handura when granted to a son and Sicke when endowed to a daughter.

Respondents in Yabello, Borana, and Atsbi said that joint household ownership of resources was the norm. Further probing, however, revealed more complex patterns of ownership mediated by gender, marital status, age, wealth, and ethnicity. For instance, respondents indicated Handura is normally a bigger share than Sicke. Moreover, in Borana, while boys can own resources before marriage, girls are not allowed to own resources (such as livestock) before marriage.

Most of the married male and female respondents reported joint ownership of cattle. However, some of the men interviewed felt that women did not own resources such as oxen and land. Widowed women indicated that they mostly owned small ruminants and poultry. Although it is acceptable for widows to own larger livestock, limited financial resources as well as a lack of labor in their households were said to affect their ability to acquire them.

Farmland is mostly owned by elderly men and women, married men and women, and the wealthy. Grazing land and water, on the other hand, are communally managed and allocated to community members by the government. In Ethiopia, land is owned by the government and community members have user rights. Once a family member (normally the husband) is allocated user rights by the Kebele chief, the land is perceived to be a family resource. In Atsbi, land ownership was certified. Both men and women respondents in Golgol Neale and Habes reported that land certificates bore the husband or father's name. In contrast, land ownership in Borana was informal, being dependent on how long one used the land. Across all three study sites, the movement of men to cities or towns to engage in retail business has increased ownership of resources by women and poorer farmers $\mathrm{f}^{\mathrm{f}}$.

In Nicaragua, in both Camoapa and Matiguás, land is privately owned by either men or women, in most cases with a written contract. Although land has been most commonly obtained through inheritance or purchasing, there were differences between men and women's responses: Women explained they own land through inheritance or because they became widows, whereas men either inherited from their parents or purchased it. Men and women respondents agreed that the most common system of resource ownership in both communities was the joint system, wherein the assets legally belong to the head of the household (male or female) but members of the family informally (i.e., via an oral agreement) own part of the resources.

Regarding livestock, women respondents stated that their cattle were given to them by their husbands or parents as gifts. Interviewed widows owned larger numbers of animals than married women because the widows had obtained cattle that had been owned by their late husbands. In general, respondent men were said to own more cattle than respondent women, and men were also more involved in supervising the farm including the land and cattle owned by women. Meanwhile, women respondents stated that they were less engaged in cattle raising activities due to household and care work, even if they owned part of the cattle. In the cases of inheritance, children receive land and cattle and are responsible for looking after them and for sharing revenues with the family. Some of the respondents said that inheritance is given to daughters and sons alike, but others mentioned that sons receive more land and cattle than daughters.

Most of the respondents from the three countries, whether male or female, started our discussions with a clear sense of who owned what resources (see previous sections). Their opinions, however, became more complex and blurred as our discussion proceeded and various points of view were shared. In Tanzania, only one young woman (from Viti) stated that the concept of ownership was complicated in her community and might vary depending on the resource and its utilization: "Here ownership is understood in terms of milking, feeding, cleaning the houses and selling! What are you referring to?"

\section{Understandings of ownership}

The following section presents different understandings of ownership by the respondents based on seven separate domains that emerged from the discussion.

\section{Benefiting from the livestock}

In Tanzania, 14 respondents associated ownership with one's ability to benefit from the livestock. The respondent men from Wami Dakawa stated that if the male head of the household died and his children were too young to take authority over the livestock, a male family member would be assigned the management of the livestock (including performing all decision-making activities); and yet, the livestock were said to belong to the family of the deceased brother because they would be the ones to enjoy the benefits generated by the livestock. A woman in Manyinga made a comparison between livestock and water by saying that, in her community, water starts out as communal but that she can come to own it if she invests in digging a well and people pay her to get the water. This shows that in this case, ownership was associated with either benefits or investment. In Wami Luhindo, the men argued that different types of ownership apply to the sale of livestock: Women sell and benefit from the revenues of smaller livestock and milk while men sell and keep the revenues from larger livestock. In Wami Sokoine, a woman and a man maintained that a woman's control over milk would pass on to her husband if the quantities of milk-and therefore the related benefits derived from owning the livestock-increased. 
In Ethiopia, ownership of a resource was also associated with the ability to benefit directly from it. When household members, women or men, contributed to the management of livestock and consumed related products, they claimed ownership of the animals. Respondent women in the three Kebeles added an interesting dimension: They said that their households' control over resources gave them social status, respect, and recognition from the community and that these non-material benefits in turn provided them with a sense of ownership.

\section{How livestock was sourced}

In Tanzania, there were various categories of ownership associated with various forms of livestock sourcing. Livestock received as "presents" were also a key element of ownership. In Wami Dakawa, boys and girls were assigned a cow by their parents at birth (see previous section). In Viti, women were said to clearly own livestock if the husband had purchased one and assigned its ownership to them. In the same village, three respondent women owned cows after they joined a dairy cooperative and received a cow from the NGO Heifer. These women made all the decisions and reaped all the benefits related to the cow. In this same village, the men stated that women could also own cows if, for example, the women earned money through the sale of crops they planted and, in agreement with their husband, had bought the cows with that money. Ownership was also associated with "dowry": An old man said that in his village, livestock was co-owned, and if the couple split up, they either shared the livestock or sold it and shared the revenues. However, in case animals were received by the wife as a dowry, the men would not be able to claim them. A young woman from Lwandai said that if there was a conflict over ownership, the contenders could trace how the animal was sourced in order to decide who owned it.

In Ethiopia, both men and women respondents indicated that a person could be said to own livestock if they had purchased it, received it as marriage gifts, and/or inherited it. However, more respondent men than respondent women had purchased livestock before marriage; and while respondent men and boys had inherited livestock and land, respondent women had inherited none. Only one male and one female respondent in Golgol Neale mentioned having received livestock from the government and a non-governmental organization, respectively, and claimed ownership of that livestock. Joint ownership of resources was also said to be determined via informal agreements between husband and wife.

In Nicaragua, respondent women claimed ownership of livestock when they had received the livestock as gift from parents or husbands or when they had inherited them. Ownership was also claimed over resources that formally belonged to the head of the household (man or woman) but were informally assigned to other members of the family.

\section{Decision-making}

In Tanzania, decision-making was a recurrent theme in discussions about ownership. Two older women associated ownership with decision-making and age: They stated that as women got older, they were able to decide to sell livestock and report the sale to their husbands. In the village of Viti, the women agreed that women owned chickens because they managed both the chickens and the revenues derived from them. They specified that they could ask the men to help with looking after the chickens but that this would not change ownership. The respondent women from Wami Sokoine argued that if the father died and the children were young, a male family member would own the livestock because he would decide about their management (even though the management of the benefits would be discussed with the widow) ${ }^{g}$. In Lwandai, the men argued that they mostly owned large livestock and made all the related decisions. The women from the same village also associated ownership with decision-making. A young man from the same village and one from Viti argued that even if women owned the animals, they would need to consult with their husbands out of respect.

In Ethiopia, respondent men and women associated ownership with decision-making power. Initially, respondents indicated that decision-making was performed by all household members, and therefore, the resources were jointly owned. They added, however, that men had more decision-making power over livestock and land and surely the final say about their management. Women, however, were able to make decisions about how to use and when to sell milk, butter, chickens, and eggs without consulting male household members and therefore claimed full ownership of these resources.

In Nicaragua, women respondents understood ownership as the power to decide while men associated it to both the power to decide and also to the work required in managing the farm. It is important to highlight that the majority of men and women respondents stated that decisions in their families were made jointly. But when they were asked about decisions that may lead to significant changes in cattle production (e.g., selling cattle and milk), most of male respondents and a few female respondents stated that these decisions were made by men because men were more knowledgeable. Regarding other sources of income-such as artisanal cheese making and raising chickens and pigs-women respondents stated that, because they made the decisions about selling and purchasing and were able to manage the revenues, they therefore owned these resources. 


\section{Taking care of the animals}

In the Tanzanian villages of Wami Luhindo and Lwandai, two women associated ownership with taking care of the animals. One stated: "I do all activities related to the management of the goats: cleaning, feeding, milking, selling the milk...therefore I am surely the owner of the goat!" The same association was made by the respondent women in Viti, who, however, changed their minds during our discussion and concluded that ownership was possibly associated more with decision-making.

In Ethiopia, joint ownership was associated with the division of labor: Male and female household members reported joint ownership of livestock when carrying out complementary roles in raising the livestock. Respondent women in Elwoye and Habes cited examples such as husbands being responsible for selling and buying livestock while the children herded and watered the animals and the women gathered grasses and residues to feed the livestock kept around the homestead. Both male and female respondents also highlighted that women and children owned poultry because they were responsible for their daily management.

In Nicaragua, "ownership of resources" was also linked to the gendered division of labor in the cattle raising sector, which is considered a "masculine sector." Men, in particular, considered those providing work to manage the farm as the owners of resources. Smaller animals that can be kept close to the house are usually looked after by women and therefore owned by them, according to both male and female respondents.

\section{Knowledge of resources}

In Ethiopia, ownership was associated with knowledge: Both female and male respondents argued that men owned most livestock because they had more knowledge than women (this knowledge was said to give men a "stronger ability to make decisions").

In Nicaragua, in both Camoapa and Matiguás, seven of the 12 respondents (two men, five women) associated ownership with the power to freely decide over resources, which was in turn linked to having knowledge. Men were generally considered to be more knowledgeable than women regarding livestock and farm management. Their greater knowledge was associated with their greater involvement with the farm, and this in turn was linked to men's superior physical strength. Because the work women did around cattle (cleaning of the animal milking and eating area, milking cows, processing milk to make artisan cheese and calf weaning) was considered part of their domestic workload (vs farm work), their related knowledge was not associated to ownership of livestock.

\section{Having full authority over livestock}

A widow from Wami Sokoine in Tanzania felt she was the owner of the livestock because she controlled all phases of management, including marketing and managing revenues. In Viti, one young and one middleaged man argued that purchasing and deciding over resources is "having full authority over them" and thereby determined ownership.

\section{Carrying the responsibility}

Male respondents from Nicaragua emphasized that, in their communities, men were considered to be the owners of the resources and livestock because they carried the responsibility of running the farm.

\section{Gender norms behind ownership}

This section looks at what gender assumptions seemed to affect the assignment of ownership within households.

Various reasons were reported to explain why men owned most and larger livestock in Tanzania if compared to women. In Wami Dakawa, the men gave a practical explanation: Women were in charge of household chores and were often pregnant and therefore needed to stay at home. For this reason, women can have small animals that are kept in the courtyard. Men, on the other hand, are given larger livestock that they need to take to the savannah for grazing. A male pastor from the same village added that some of the widows managed the family alone very well, and he concluded, "Women are able to manage their household alone indeed!" Another man added, "Daughters can't take care of the livestock because they might marry and leave the family anyway." The strong role of men in this community was shown by the fact that, during the interviews, the women needed to ask for men's permission to speak.

In the village of Lwandai, the women and men attributed the ownership system that favored men to their traditional customs. One man referred to the Bible to say that men are the heads of the household and therefore own its resources. The respondent men from Lwandai added that "schooling" is what can contribute to women taking good care of their families and being capable of managing the resources they own. In the village of Viti, men's ownership of most resources was attributed to a man's traditional role as food provider. One male respondent referred to a national law that, in his opinion, established a woman's role as family caretaker and cook and a man's role as food provider. A second man referred to the Bible to explain that men are the heads of households and women cannot make decisions alone. In Wami Sokoine, a young man argued that "Women are normally weak. If they are given ownership they will not satisfy the food security of the household." Another young man added, "Also, we have extended 
families and men can have more wives and it becomes difficult to decide which one of them will own or make decisions." A young woman also mentioned polygamy as the reason for men's ownership, while a second young woman stated strongly that women were able to both own resources and contribute to food security. An older woman from the same village responded that some men were not able to take care of the families either and depended on their wives. When asked if women's ownership of livestock was embarrassing for the men, most men in all villages argued that on the contrary, they are proud of having a wealthy wife.

In Ethiopia, the male and female respondents argued that women were considered capable of fully owning poultry and making independent decisions about milk, butter, chickens, and eggs because these were resources that could be managed within the household compound which was "the appropriate place for women."

Men were said to own more livestock than women because they were perceived to be more knowledgeable about the subject. Women, however, thought they were more knowledgeable about issues related to food. However, both male and female respondents in Golgol Neale noted a growing change in such norms and beliefsmore women were owning resources usually associated with men, especially land and cattle. This was attributed to the community's acceptance of women's roles and rights due to awareness raising on gender and gender equity, and also government initiatives to increase resource ownership by women.

In Nicaragua, one male respondent from Matiguás stated that if he had to think of a percentage of men who talked to their wives before making livestock decisions, it would be around $20 \%$. This is because women are seen by community members as "unable" to manage a farm. Male respondents argued: women are "not knowledgeable enough," "they are not as physically strong as men," "domestic work takes all their time," and "they do not have the required authority to manage a farm." The respondent women who associated ownership with decision-making stated that the most important decisions about cattle were made by or with men because they "trusted" that men made better decisions because they worked with the cattle all day and had more knowledge about their management (see the "Knowledge of resources" section).

\section{Implications of the meanings of ownership for food security}

This section connects the meanings assigned to ownership to their implications for household food security.

In Tanzania, because men are generally considered to be responsible for food security, the money earned by them was supposed to be invested in household food expenditures. However, many respondent women thought men often invested money in personal expenses rather than household expenditures. The money that women earned-through the livestock they owned, the crops they grew, and the sale of milk-was used for household expenses such as school fees, utensils, medicines, etc., as well as for collateral in case of a difficult situation. (This protection from shocks can also arguably be important for food security). The respondent women, however, mentioned that if they had more control over resource revenues, they would take better care of household food security. The women from Wami Dakawa, for instance, believed that owning livestock would entail an increase in decision-making power, which in turn would improve household food security.

In Lwandai, the women argued that if they owned livestock, men could not make decisions about managing earnings alone and also could not forbid women from pursuing investment choices that would increase food security. In Masinyeti, both women and men who participated in the CGP project and co-owned the dairy goats distributed by the project argued that co-ownership guaranteed much better management of the goats, since both women and men felt responsible for their management. Better management was directly related to improved food security.

In Ethiopia, both male and female respondents strongly emphasized how joint resource ownership is positively linked to food security, claiming that such ownership fosters the efficient utilization of resources needed to increase production of milk, meat, butter, and eggs. However, the respondent women stated that ownership and independent decision-making power over larger livestock could be an important way of increasing their control of household food security. But they added that ownership of livestock was not a sufficient means of increasing food security, since other agricultural activities would still be reserved exclusively for men. For instance, although women household heads could own cattle, they could not use the cattle to plow land, a labor-intensive activity considered more appropriate for men. These women indicated that a more gender-equal ownership system would require more flexible gender norms in the division of labor in order to improve food security. Finally, the poorest women and men believed that costly livestock (e.g., camels or oxen) increased household food security by enhancing the resilience of households against shocks and by saving money that would have been spent on hiring oxen to plow land.

In Nicaragua, most of the respondents from Matiguás and Camoapa agreed that decisions about food were made jointly but added that there are gendered divisions in managing money and food. Men and women respondents agreed that it was women who managed and bought food, but it was men's responsibility to provide most of 
the household income (which primarily came from cattle production). In other words, women were the financial administrators of the households but they relied on the milk- and animal-based revenues they received from men. This, the women believed, reduced the efficiency of food security strategies, particularly in cases when men refused to spend revenues on non-household needs, spent revenues on personal needs, or were not good cattle producers.

\section{Discussion}

\section{Meanings of ownership}

In line with the literature on the complexity of ownership arrangements, our findings strongly point to the flexibility of these arrangements-they vary by age, gender, household and personal circumstance, geographical location, gendered perceptions of knowledge and physical strength, legal registration, and labor allocation. Our findings also show that the respondents found it important to distinguish between ownership, access, and control when it comes to the resource arrangements that have been highlighted by Ribot and Peluso. As a matter of fact, the term "joint ownership" meant "shared labor tasks" in Ethiopia, "shared legal rights" in Tanzania, and "legal rights of the household head in conjunction with informal rights of other household members" in Nicaragua.

This paper shows that even within the small cohort focused on in this study, we found seven different domains of ownership. Most of these domains were mentioned by women and men alike across the three countries-meaning that we found no single country- or gender-specific understanding of ownership ${ }^{\mathrm{h}}$. Also, it shows that already-ambiguous understandings of ownership are made even more ambiguous by the informal nature of livestock ownership arrangements (as compared to land, for example). Therefore, we argue that researchers should not assume that their own understanding of ownership coincides with the local understandings and that a community shares a single understanding of ownership; rather, researchers need to unpack the very concept of ownership and understand its local permutations.

We argue that engaging with local explorations of the term "ownership" - particularly from a gender perspectiveand unpacking the term into its discrete components (e.g., by asking for a given asset "who is involved in decision-making, labor, or revenue control" rather than "who owns it") can help elucidate the roles of farmers or livestock keepers in the livestock and food value chains. The utilization of the term "resource ownership" in tools-and particularly surveys that do not engage with more in-depth analysis-risks glossing over a number of social arrangements related to management, decision-making, and labor and might calcify them into categories that rarely reflect the complex reality on the ground. Such calcification is troubling, since it can be used to inform the design of development interventions.

\section{Enhancing food security and gender equity}

In the three languages of this study, the terms used for "ownership" (and associated words) seemed to the authors to not necessarily convey gender biases (e.g., both the feminine and masculine forms of the term exist). Gender biases, however, emerged from the lived experiences of ownership (i.e., "owning larger livestock is improper for young women"). Also, while the article shows the lack of a shared concept of ownership, it does show enduring gendered regularities of human action in a situation structured by rules, norms, and shared strategiesCrawford and Ostrom's 1995 definition of "institution"in the distribution of resources. This suggests an institutionalized gender-biased distribution of resources (in Ostrom's sense). In other words, regardless of what meanings were associated with ownership, arrangements to govern resources (particularly in the cases of the most valuable resources) were biased in favor of men. These biases were affected by gender identities that socialize men and women into what are considered to be "appropriate behaviors." These normative behaviors in turn affect how women and men understand ownership, their lived experiences of resource ownership, and who is involved in various food production, provision, and preparation activities-all of which ultimately had an impact on household food security. As an example, the evidence from Nicaragua shows a direct link between traditional gender roles (women burdened with domestic and productive work, as well as considered less knowledgeable than men about cattle farming) and the understanding of ownership (i.e., who possesses more knowledge is better prepared to make decisions about a resource). This in turn affects women's capacity to ensure food security for their households, since they are hindered from contributing to a vital source of income.

Given the different perceptions of the meaning of ownership, the gender-unequal resource distribution, and their impact on food security, this paper argues that an exploration of local meanings of ownership can provide a means of appreciating local priorities and preferences related to resource ownership. Such an appreciation can help improve initiatives (such as CRP L\&F) that aim to enhance food security and intrahousehold gender equity. Evidence from Ethiopia, for example, shows that enhancing women's access to and control over resources would need to be paralleled by a support for more flexible gender norms so that activities important for food security could be performed by women and men alike.

Our findings have important implications also for understanding the links between decision-making, gender 
equity, and food security. Egalitarian decision-making among men and women is defined by Doss et al. [2] as when responses about decision-making "show a similar and symmetrical pattern," "are confirmed by each other's response," and "reflect mutual consultation." When situated within this framework, the three countries examined exhibit non-egalitarian patterns, with women having a disadvantaged role in decisions about resource management. The respondent women from these countries believed that more control over resources would increase their independence, as well as their control over food and household food security. This is in line with the literature that connects women's control over resources and improved household food security. However, the findings from the three countries show that men also considered decisionmaking and control over resources as important to food security. Male and female respondents from Masinyeti who co-owned resources mentioned the importance of managing resources together and how sharing responsibilities was a way of enhancing food security.

Will increasing women's control over resources and food security give them the role of food providers, thereby disengaging men from that role? Or will it promote an equal sharing of food security tasks? Agarwal [27] argues in favor of individual ownership titles for women because of their flexibility, as well as their validity in case of marital conflict. Jackson [28], on the other hand, discusses the high social costs that obtaining individual rights might entail when such rights contrast with norms.

This paper argues that assessing local meanings of ownership and the gender norms behind them can help reveal pathways toward new gender roles that will be acceptable at the household and community levels (as was mentioned by female respondents from Ethiopia). The paper highlights the need for development projects not only to have an understanding of the multiple facets of resource ownership and related social arrangements but to also leverage these in order to create new arrangements and gender spaces, i.e., "stretching the existing space of what is possible." Ison et al. [29] speak of "paying more attention to supporting existing social practices that have widespread legitimacy, rather than to developing expensive solutions to replace them." For example, the positive perceptions that female and male respondents in Tanzania had of co-ownership arrangements supported by the Heifer and CGP projects indicate that space does indeed exist to change normative gender roles and allow for a different distribution of entitlements and also tasks and decision-making abilities.

The way in which perceptions of ownership and ownership arrangements strongly affected decision-making, division of labor, control over income, enjoyment of resource benefits, and food security seems to suggest that they might also affect household decision-making regarding technology adoption. This issue, however, was not within the scope of our study and merits further scrutiny.

A methodological consideration is the following one: the psychological ownership literature identifies the elements behind a sense of ownership: "controlling," "intimately knowing," "investing oneself," and "a shared understanding." These elements can be linked respectively to the categories identified in this paper: "decision-making," "taking care of the animals," and "how livestock was sourced" (in our study, these include both monetary investment and "being informally but officially assigned a resource"). However, this study also mentions "having full authority over livestock," "benefiting from the livestock," "knowledge of resources," and "carrying the responsibility." Establishing the key elements of "local understanding of ownership" might be best done via exploratory studies-like the one presented here-rather than via pre-established criteria or frameworks. The former occurred in the study by Marks and Davis, which at the outset assumed key causal elements informing a sense of ownership and used those elements to quantify the sense of ownership, all the while without questioning or testing these elements' relevance on the ground. Crawford and Ostrom [29] provided a framework to study local institutions such as property, which is based on a definition of institutions as "shared concepts used by humans in repetitive situations organized by rules, norms, and strategies" [30]. This paper, however, shows that while not all respondents of this study shared the same concept of "ownership," gender-biased systems of resource governance seemed institutionalized. A study of these systems through the framework provided by Crawford and Ostrom could help appreciate the reasons behind the reported discrepancy between men's and women's statements on ownership arrangements: Because the discrepancy was apparently not motivated by different understandings of ownership, were the statements shaped by "locally appropriate gender discourses" that varied among and within communities?

\section{Conclusions}

This paper explored how 71 women and 67 men from Tanzania, Ethiopia, and Nicaragua understood "resource ownership," especially livestock ownership. The seven ownership domains identified were "benefiting from the livestock," "how livestock was sourced," "decision-making," "taking care of the animals," "knowledge of resources," "having full authority over the livestock," and "carrying the responsibility." The study described how distribution of resources in the respondent households varied by age, gender, household and personal circumstance, geographical location, gendered perceptions of knowledge and physical strength, legal registration, and labor allocation, and it also presented the gender norms that affect this distribution. It 
showed the implications of these understandings on intra-household roles, decision-making, and ultimately food security. Evidence from the study also showed that arrangements to govern resource-particularly in the case of the most valuable resources-were biased in favor of men.

We conclude that, rather than assessing "who owns what resources" that seems to mean little, researchers need to ask more specific questions about resource management and benefit sharing based on the study focus. We argue that exploring local meanings of ownership can provide a way of appreciating local and intra-household priorities and preferences related to resource ownership. Such an appreciation can improve projects (such as CRP L\&F) that aim to enhance intra-household gender equity and food security. We raise questions about whether women's individual resource ownership would support household equity and food security or if it would tie women to the role of food providers and thereby disengage men from that role, and also whether joint ownership would help promote an equal sharing of food security tasks between husbands and wives. We argue that it is necessary not only to appreciate complex understandings and arrangements of resource ownership but to also leverage our knowledge of these understandings and arrangements to foster new social arrangements and gender roles.

\section{Endnotes}

${ }^{a} \mathrm{~L} \& \mathrm{~F}$ focuses on meat, milk, and fish value chains worldwide in order to enhance gender-equal food security and livelihoods for the most poor. See CGIAR [http://livestockfish.cgiar.org/].

${ }^{\mathrm{b}}$ Both projects address small livestock keepers in rural communities in Tanzania. MoreMilkiT aims to ensure that rural poor are more income secure via enhanced access to demand-led dairy market business services and viable organizational options. CGP aims to improve household income, food security, and the well-being of poor and women-headed households in agro-pastoral communities via a community-based crossbreeding program for dairy goats, as well as via improved participatory farm trials for cassava and sweet potato varieties.

${ }^{\mathrm{c}}$ These criteria included the following: the significant food security, economic, and cultural roles of small ruminants for smallholder rural poor households within selected areas; the potential to build on the existing momentum of previous efforts to develop small ruminant value chains; the likelihood for project research to contribute to improved quality of animal breeds and feed supply, and development of producer and breeder groups; the potential to create and enhance market infrastructure and institutional markets related to small ruminants; and the potential positive contribution to the adaptive capacity of households in relation to changing drought cycles in the project areas.

dThe literal translation of ownership is "propiedad," and in this sense, the person who owns would be "propietario" (if it is a man) or "propietaria" (if it is a woman); but in Nicaragua, this word is commonly linked to someone who owns a property such as a house or a building and it is used in a formal manner.

${ }^{\mathrm{e}}$ These included owner, resources owned, system of ownership, meaning of ownership, implications for food security, implications for gender relations, and gender norms affecting ownership.

${ }^{\mathrm{f}}$ At the time of the study, the Ethiopian government was also promoting allocation of land to women and youths. During interviews, women and men respondents from Golgol Neale and Habes acknowledged resource ownership is shifting, in part because of these changes in policy. Women (including female household heads) and youth are now more likely to own resources, especially land.

${ }^{\mathrm{g}}$ This is in direct contrast to Wami Dakawa, where in similar circumstances ownership was perceived to stay with the widow (see the "Benefiting from the livestock" section).

${ }^{\mathrm{h}}$ However, "taking care of the animals" in Tanzania was mentioned only by female respondents and "carrying the responsibility" of managing the farm was mentioned only by men in Nicaragua.

\section{Competing interests}

The authors declare that they have no competing interests.

\section{Authors' contributions}

AG contributed to conceptualizing the research, providing the findings from Tanzania, writing most of the article, and leading its development. AM participated in the design of the study, collected and analyzed data from Ethiopia, and participated in drafting the manuscript. MAMB participated in the methodology and design of the study and drafted the Nicaragua sections of the manuscript, with guidance from AG and SNO. SNO contributed to revising the paper including refining the methodology section and integrating revisions and comments from the other co-authors. $\mathrm{KC}$ reviewed and made editorial comments on drafts of the manuscript. All authors read and approved the final manuscript.

\section{Acknowledgements}

The authors would like to acknowledge the support of Dr. Paula Kantor at WorldFish for her critical review of the paper, the staff of MoreMilkiT and the Dairy Goats and Root Crops (CGP) project, and the extension staff from Lushoto, Mvomero, and Kongwa districts for their logistical support. Special thanks are due to the farmers from the same districts for their availability and openness during the discussions reported in this paper; to the Index-Based Livestock Insurance (IBLI) team at ILRI, Kenya, in particular Anne Gesare, research analyst, IBLI, for assistance in obtaining information on population and household characteristics for Yabello district, Ethiopia; and to Julius Githingi, research technician, MoreMilkiT project at ILRI, Kenya, for assistance in obtaining household characteristics information for Lushoto district, Tanzania. The authors are also grateful to the research assistants who collected data; to the translators and livestock keepers in Ethiopia who participated in the study; and to the Association for Municipal Development and the Women's Group for Advocacy of Camoapa, Nicaragua, especially Ivania Ampié, Jasmina Miranda, and Ivania Lovo who were key in the acquisition of data. 
Alessandra Galiè was funded by Irish Aid, IDRC, and the CGIAR Research Program on Livestock and Fish for her work in Tanzania. Annet Mulema, Maria Alejandra Mora Benard, Sheila Navalia Onzere, and Kathleen Earl Colverson were funded by the CGIAR Research Program on Livestock and Fish for their work in Ethiopia and Nicaragua.

\section{Author details}

${ }^{1}$ International Livestock Research Institute, P.O. Box 30709, Nairobi, Kenya. ${ }^{2}$ International Livestock Research Institute, P.O. Box 5689, Addis Ababa, Ethiopia. ${ }^{3}$ International Center for Tropical Agriculture, Planes de Altamira, Edificio CAR III, 4th Floor, Managua, Nicaragua. ${ }^{4}$ International Center Associate Director of Program Development, University of Florida, P.O. Box 113225, Gainesville, FL 32611, USA

Received: 23 July 2014 Accepted: 7 January 2015

\section{Published online: 09 February 2015}

\section{References}

1. Valdivia C, Gilles J. Gender and resource management: households and groups, strategies and transitions. Agric Human Values. 2001;18(1):5-9.

2. Doss C, Kim SM, Njuki J, Hillenbrand E, Miruka M. Women's individual and joint property ownership effects on household decision-making. International Food Policy Research Institute Discussion Paper No. 01347. 2014

3. Fafchamps M, Quisumbing A. Assets at marriage in rural Ethiopia. J Dev Econ. 2005;77(1):1-25.

4. Peterman A. Women's property rights and gendered policies: implications for women's long-term welfare in rural Tanzania. J Dev Stud. 2011;47(1):1-30.

5. Espinoza I. Perfil de género de la economía nicaragüense en el nuevo contexto de la apertura comercial. Managua: United Nations Development Fund for Women; 2004.

6. Gray and Kavane (1999) in Peterman A. Women's property rights and gendered policies: implications for women's long-term welfare in rural Tanzania. J Dev Stud. 2011:47(1):1-30.

7. Agarwal B. A field of one's own: gender and land rights in South Asia. New York: Cambridge University Press; 1995.

8. Meinzen-Dick R, Johnson N, Quisumbing A, Njuki J, Behrman J, Rubin D, Waithanji E. Gender, assets, and agricultural development programs. International Food Policy Research Institute CAPRi Working Paper No. 99. 2011.

9. Njuki J, Sanginga P. Women, livestock ownership and markets bridging the gender gap in Eastern and Southern Africa. London: Routledge; 2013.

10. O'Laughlin B. A bigger piece of a very small pie: intrahousehold resource allocation and poverty reduction in Africa. Dev Change. 2007;38(1):21-44.

11. Ostrom E. Understanding institutional diversity. Princeton: Princeton University Press; 2005.

12. Jackson C. Gender, irrigation and environment: arguing for agency. Sri Lanka: Workshop on Women and Water. Colombo; 1997. p. 15-9.

13. Razavi S. Gendered poverty and well-being: introduction. Dev Change. 1999:30(3):409-33.

14. Ribot JC, Peluso NL. A theory of access. Rural Sociol. 2003;68(2):153-81.

15. Bell D, Ribot JC, Peluso NL. A theory of access. Rural Sociol. 1998;68(2):153-81.

16. Johnson N, Njuki J, Waithanji E, Nhambeto M, Rogers M, Kruger EH. The gendered impacts of agricultural asset transfer projects: lessons from the Manica Smallholder Dairy Development Program. International Food Policy Research Institute CAPRi Working Paper No. 115. 2013.

17. Marks SJ, Davis J. Does user participation lead to sense of ownership for rural water systems? Evidence from Kenya. World Dev. 2012;40(8):1569-76.

18. Flyvbjerg B. Five misunderstandings about case-study research. Qual Inq. 2006;12(2):219-45.

19. Mahoney J, Goertz G. A tale of two cultures: contrasting quantitative and qualitative research. Polit Anal. 2006;14(3):227-49. doi:10.1093/pan/mpj017.

20. Donmoyer R. Attributing causality in qualitative research: viable option or inappropriate aspiration? An introduction to a collection of papers. Qual Inq. 2012;18(8):651-4.

21. George A, Bennett A. Case studies and theory development in the social sciences. London: MIT Press; 2005.

22. Saghir P, Njuki J, Waithanji E, Kariuki J, Sikira A. Integrating improved goat breeds with new varieties of sweet potatoes and cassava in the agro-pastoral systems of Tanzania: a gendered analysis. ILRI Discussion Paper No. 21. 2012.

23. Ministry of Finance (MoF). Ethiopia's progress towards eradicating poverty: an interim report on poverty analysis study 2010/2011. Development
Planning and Research Directorate, Ministry of Finance and Economic Development. Addis Ababa; 2012.

24. Central Statistical Agency of Ethiopia (CSA) [http://www.csa.gov.et/]

25. Borgatti SP, Halgin DS. Consensus analysis. In: Kronenfeld DB, Bernnardo G, de Munck VC, Fischer MD, editors. A companion to cognitive anthropology. Hoboken: Wiley-Blackwell; 2011. p. 171-90.

26. Caulkins DD, Hyatt SB. Using consensus analysis to measure cultural diversity in organizations and social movements. Field Methods. 1999;11:5-26.

27. Agarwal B. Gender and land rights revisited: exploring new prospects via the state, family and market. J Agrar Chang. 2003;3(1):184-224. doi:10.1111/ 1471-0366.00054.

28. Jackson C. Gender analysis of land: beyond land rights for women? J Agrar Chang. 2003;3(4):453-80. doi:10.1111/1471-0366.00062.

29. Ison R, Roling N, Watson D. Challenges to science and society in the sustainable management and use of water: investigating the role of social learning. Environ Sci Policy. 2007;10(6):499-511.

30. Crawford SE, Ostrom E. A grammar of institutions. Am Polit Sci Rev. 1995:89 (3):582-600.

\section{Submit your next manuscript to BioMed Central and take full advantage of:}

- Convenient online submission

- Thorough peer review

- No space constraints or color figure charges

- Immediate publication on acceptance

- Inclusion in PubMed, CAS, Scopus and Google Scholar

- Research which is freely available for redistribution 